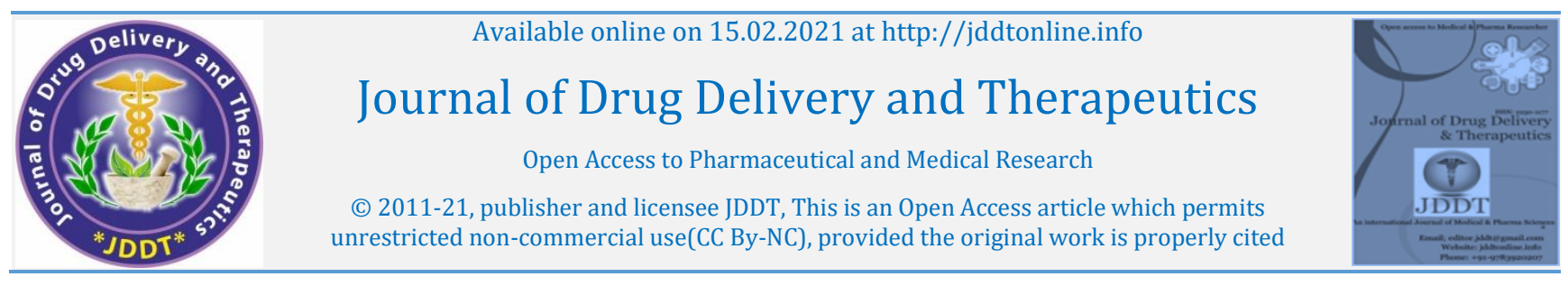

Open Access Full Text Article

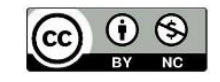

Review Article

\title{
A review on ethnobotany, phytochemistry and pharmacology on Terminalia belerica (Bibhitaki)
}

\author{
Panshul Sharma, Kapil Kumar Verma*, Hans Raj, Nutan Thakur \\ School of Pharmacy, Abhilashi University, Mandi-175028, Himachal Pradesh, India
}

\section{Article Info:}

\section{Article History:}

Received 28 Nov 2020;

Review Completed 22 Jan 2021

Accepted 30 Jan 2021;

Available online 15 Feb 2021

\section{Cite this article as:}

Sharma P, Verma KK, Raj H, Thakur N, A review on ethnobotany, phytochemistry and pharmacology on Terminalia belerica (Bibhitaki), Journal of Drug Delivery and Therapeutics. 2021; 11(1-s): 173-181

DOI: http://dx.doi.org/10.22270/jddt.v11i1-s.4739

\section{Abstract}

Terminalia belerica Roxb. is belonging to family combretaceae, which is growing widely throughout the Indian subcontinent, Bangladesh, Nepal, Sri-Lanka, and South East Asia. It is is used in several traditional medicines to cure various diseases. There are different phytoconstituents Glucoside, Tannins, ellagic acid, ethylgallate, gallylglucose, chebulanic acid which are responsible for its wide therapeutic actions. It is mainly used as antioxidant, antimicrobial, antidiarrhoeal, anticancer, antidiabetic, antihypertensive and hepatoprotective agent. This review article sites the information of different pharmacological activities of Terminalia belerica which may be source for further research studies.

Keywords: Phytoconstituents, pharmacologicalactivities, Terminalia belerica, therapeutic actions.

\footnotetext{
*Address for Correspondence:

Kapil Kumar Verma, School of Pharmacy, Abhilashi University, Mandi-175028, Himachal Pradesh, India
}

\section{INTRODUCTION}

Herbal medicines are used as a health care tool in various countries. All the developing countries are fully dependant on herbal remedies ${ }^{1}$. Bibhitaki, also known as Baheda in $\mathrm{Hindi}^{2}$, is one among three fruits of Triphala. Triphala is one of the Ayurvedic formulaions which may have antifungal, antibacterial, laxative, hypolipidimic, antidiabetic and immunomodulatory activities ${ }^{3}$. Triphala or its constituents used against infectious microorganisms also ${ }^{4}$. Bibhitaki means the fruit that takes away the fear of disease.Its botanical name is Terminalia belerica belongs to family Combretaceae 5 . A plant with active medicinal properties or constituents are used to treat disease in the traditional systems like Ayurveda, Siddha and Unani6,7. Herbal medicines are prepared from different plant materials such as leaves, stems, roots, bark etc. They mainly contain biologically active ingredients and are used primarily for treating mild or chronic ailments ${ }^{8}$. Ayurvedic remedy is commonly used in India. Maximum the Ayurvedic formulations are good in cold, cough, dysentery and increases appetite. Baheda fruit may contain chemicals such as tannins,elegiac acid, beta cetosterol 9. A ripened plant of Baheda used as a purgative. All medicinal plants are used to cure all disease which may affect the Human being ${ }^{10}$.

According to Ayurvedic principles this fruit(T. belerica) may increase the dryness of the tissue which may leads to ingest ${ }^{11}$. Bibhitaki primarily supports formation of three body tissue i.e. nutrients plasma (rasadhatu), ISSN: 2250-1177 muscle(mamsadhatu), bone(asthidhatu). It is a powerful medicine for a vaiety of lung conditions, in which bronchitis and asthma are involved. Plants produce a wide array of bioactive principles amd contains a rich source of medicines. It grows all over India ${ }^{12}$. In India, 45,000 plant species have been identified and out of around 15 to 20 thousands plants are found which may have good medicinal value ${ }^{13,14}$.

\section{SYNONYMS}

1. Assam: Bhomora, Bhomra, Bhaira

2. Eng: Beleric, Myrobalan

3. Gujrat: Bahedam, Beheda

4. Hindi: Bahera

5. Kan: Shanti, Shantikayi, Tare,

6. Mal: Tanni, Tannikai

7. Mar: Beheda

8. Ori: Beheda, Bhara

9. Sanskrit: Vibhita, Aksa, Aksaka, Bibhitaki

10. Tam: Thanakkai, Tanri, Tanirakkai

11. Tel: $\quad$ Tannikkaya, Vibhitakami, Tan ${ }^{15}$

\section{BOTANICAL DESCRIPTION}

Terminalia belerica Roxb. (Combretaceae) is mostly found in decidous forests in India except a dry area ${ }^{16}$.In India the tree is mainly found in forests of Assam, Gujrat, Odissa, Andhra Pradesh, kerala, Tamil Nadu. Baheda is a large deciduous tree with broadly leaves cluster at the ends of the branches, a thick brownish grey bark, attaining a height 20 to 30 meters 
in elevation 17. The leaves are crowded around the ends of branches. Leaves are petiolate and around $8-20 \mathrm{~cm}$ long. The flowers are pale greenish yellow. Flowers arise from spikes of the leaf axils. Stamens are 3-5 mm long. The fruits are ovioid grey drupes with $1.5-2.5 \mathrm{~cm}$ in diameter ${ }^{18}$. It is wildly distributed throughout the world especially in Indian subcontinent. Srilanka, Pakistan, Nepal and South East Asia ${ }^{19}$ This fruit is also known as Beleric Myrobalan in English, Bhibhtaki in Sanskrit, and locally it is known as Bahera in India. Various phytochemicals has been isolated from different parts of the plant in which alkaloid, coumarin, flavones, saponin, tannins, glycosides, terpenoid etc. are included 20 .

Biology-flowers matured in the month of october-november and fruits in november-december. The tree shed leaves in November with young ones appearing with flowers ${ }^{21}$.

\section{BIOPHYSICAL LIMITS}

\section{Altitude-0-2000m}

Mean annual rainfall-900-3000mm

Mean annual temperature-22-28degree C

Soil type-fertile soil and good drainage.

\section{PLANT DESCRIPTION}

\section{Family Name: Combretaceae}

Kingdom: Plantae
Division: Magnoliophyta

Class: Magnoliopsida

Order: Myrtales

Family: Combretaceae

Genus: Terminalia

Species: belerica ${ }^{18}$

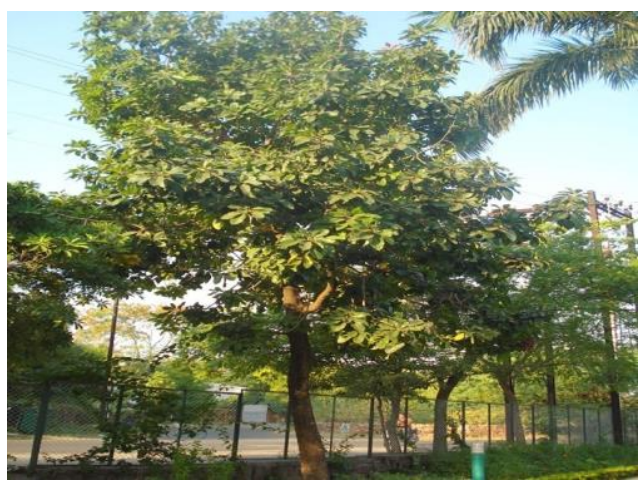

Figure 1: Whole Plant (Bibhitaki)

\section{PHYTOCONSTITUENTS}

Many of researchers have investigated T. belerica for its many biologically active phytochemicals. Some of phytochemicals are shown in Table 1.

\begin{tabular}{|l|l|l|l|}
\hline S. No. & SOURCE & \multicolumn{1}{|c|}{ PHYTOCHEMICALS } & Ref \\
\hline $\mathbf{1 .}$ & Plant Body & $\begin{array}{l}\text { Tannins, gallic,ethyl and ellegic acid, galloylglucose, flavones, fructos, rhamnose, coloring } \\
\text { matter, resins pheyllemblin etc. }\end{array}$ & $22,23,24$ \\
\hline $\mathbf{2 .}$ & Seed & Cardenolide, cannogenol3-0-D, phospholipids 14. Etc & 25,26 \\
\hline $\mathbf{3 .}$ & Fruit & $\begin{array}{l}\text { Tainternilignan, thannilignan, flavones, anolignan B 5, gallic acid, beta setosterol and } \\
\text { tannins. Alkaloids, saponin, polysaccharides, Steroid, belleric acid, galactose, chebulagic } \\
\text { acid. Phenols, carbohydrates, and proteins etc. }\end{array}$ & $27,28,29,30$ \\
\hline $\mathbf{4 .}$ & Stem bark & $\begin{array}{l}\text { Arjunogenin and its glycosides, belleric acid and bellericosides. } \\
\text { Hydrolysable tannins, gallicacid, in the water soluble extracts. }\end{array}$ & 25,31 \\
\hline $\mathbf{5 .}$ & Leaf & $\begin{array}{l}\text { Proteins, steroids and terpenoids. } \\
\text { Three hydrolysable tannins, gallic acid, ellagic acid and methyl gallate, leutolin, quercitin } \\
\text { 3-O-a-L-rhamnosepyranoside. } \\
\text { Saponins, tannins, amino acids, alkaloids, carbohydrates, 4-hydroxy-benzoic acid. } \\
\text { Pyidine-30carboxamide, 4-dimethylamino-N,2,4-difluorophenyl beta-setosterol, etc. }\end{array}$ & $32,33,34$ \\
\hline
\end{tabular}




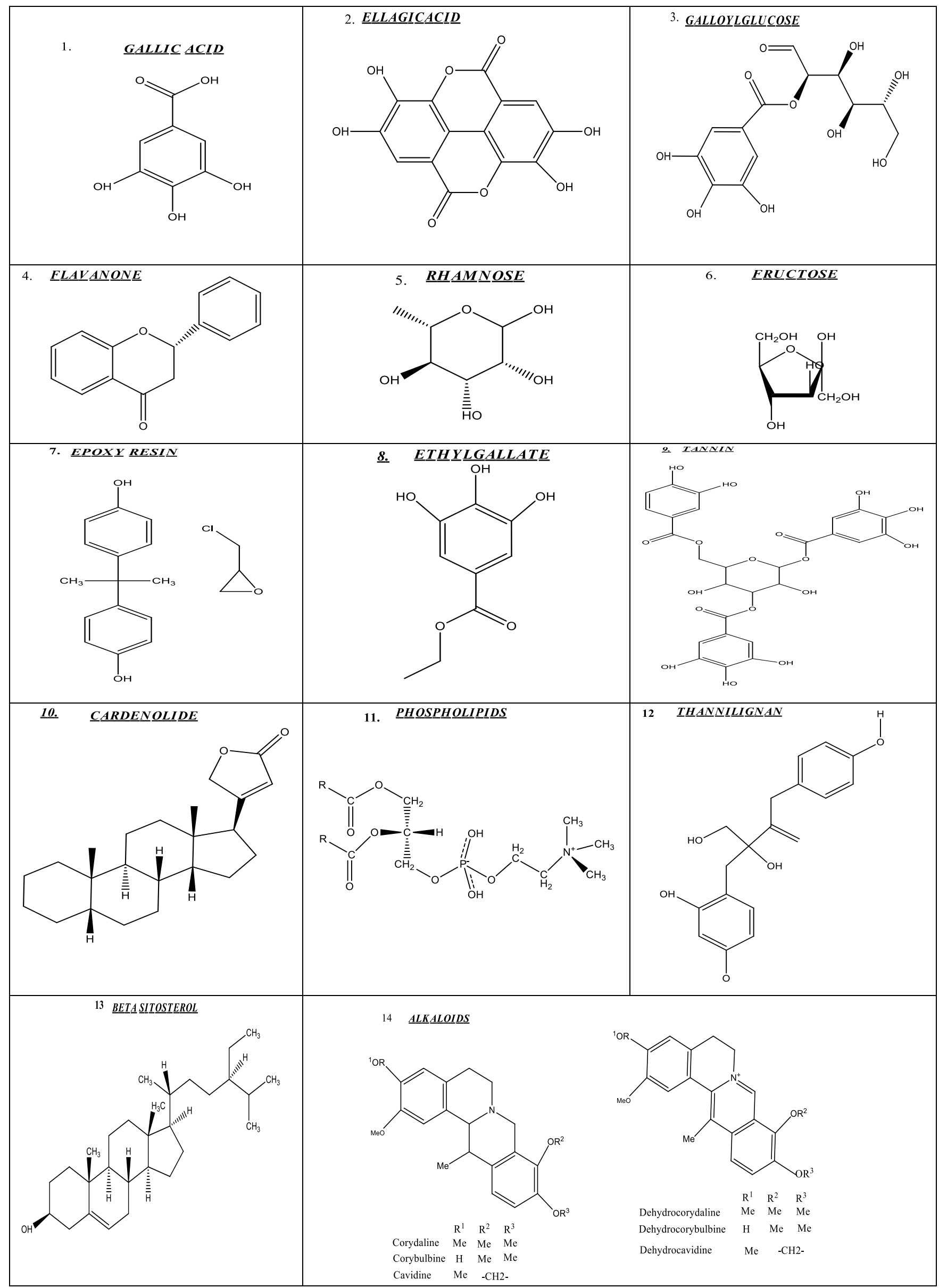




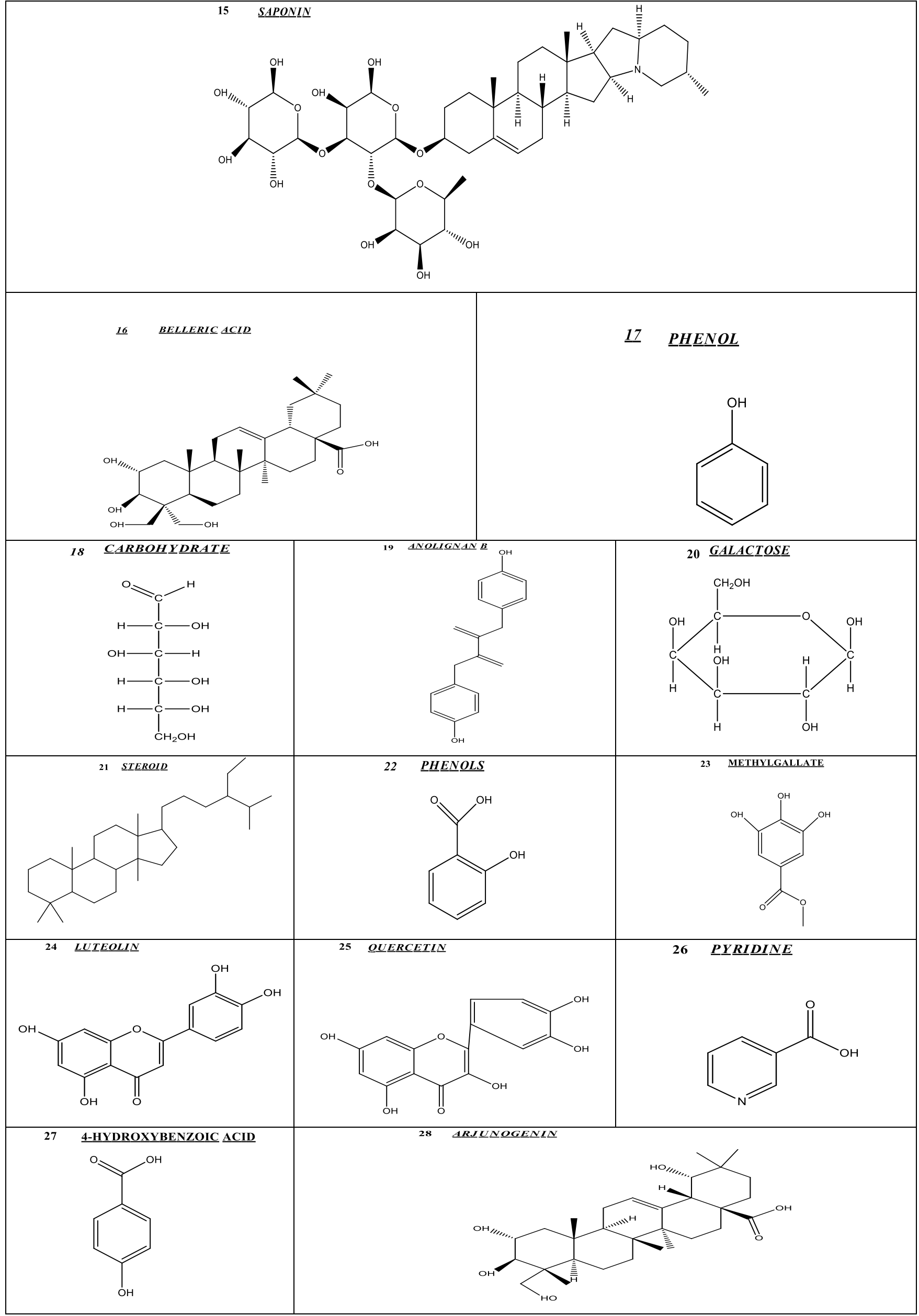




\section{AYURVEDIC PROPERTIES}

Bhedanam: Eases motion, has laxative action. This is why Immunomodulatory Activity

Triphala is used as mild laxative.

Kasanashanam: relieves cough, cold

Netrahitam: good for eyes

Keshya:improves hair quality and promotes hair growth

Kruminashanana: relieves worm infestation

Vaisvaryanashan: relieves hoarseness of voice

Chardi: Vomitting 20

\section{TRADITIONAL USES}

In Ayurveda, the drug $T$. belerica is identified as an expectorant. It is an integral part of Ayurvedic laxative ${ }^{35}$, astringent, anthelmic, and antipyretic which is useful in hepatitis, bronchitis, piles, coughs, eye disease such as myopia, corneal opacity etc. hoarseness of voice, it is also used as hair tonics ${ }^{36}$. It has lithotriptic, rejuvenative and antibacterial properties. The fruits are used in astringents, digestive, aperients, stypic, narcotic, Unripe fruit is a mild laxative and ripe fruit is an astringent ${ }^{37}$.Decoction of the fruit is used for cough. Flowers are greenish-yellow, borne in axillary, and having offensive odor. Stem are straight, frequently buttressed when large ${ }^{24}$. The bark is midly diuretic acid and also useful in anaemia and lucoderma. The palnt may contain seed oil which is used in rheumatism. Maximum the triterpenoids present in the fruits possess antimicrobial activity. T. belerica also promotes hair growth ${ }^{38}$. The fruit is chewable and curable for cough, cold etc. Baheda as also useful for diabetes, urinary disorder. The oil of Kernel may use in mice as purgatives ${ }^{39}$. Vibhitaki is used primarily to lower kapha- related diseases and respiratory disorders. It can expel stones or other types may assemble in digestive, urinary, and respiratory tracts 40 . One third of classic formulations Triphala, known as cleanser and nourisher of kalphadosha. Useful for maintainance of balancing the body including the body fluids. It is also used in treating disorders relating to the manipura chakra relating to functions of abdominal nervous system ${ }^{41}$.

Recent research shows that bibhitaki reduces levels of lipids; fatty acids through the body ad specifically lower the lipid levels in the liver and heart. This shows a strong action in preventing heart, liver and fat congestion ${ }^{42}$. As a daily rejuvenating an preventive supplement bibhitaki is good, especially for kapha body types ${ }^{43}$.

Digestion: It is known as the best tonics for the digestive systems, Bibhitaki juice keeps the system clean and resolves the digestive functions. Respiratory System: Problems related to respiratory such as asthma, bronchitis and phlegm can be prevented by Bibhitaki ${ }^{44}$. Cuts and Wounds: Applying Bibhitaki paste on cuts and wounds can be prevented excessive bleeding. For Dry and inflamed eyes: Mainly the physician recommends ghee processed with Bibhitaki, amla and haritaki in treatment of dry and inflamed eyes ${ }^{45}$. For cough, cold, and bad throat: The small bits of pulp of dry bibhitakifruit has to be fried in pure ghee. These bits are chewed slowly to get relief
in cold, cough and bad throat. Diabetes: Bibhitaki can be effectively used in diabetes. Then it normalizes kapha and medhas, which are main cause of diabetes ${ }^{46}$.Irritable bowel syndrome: The dry fruit powder of this fruit help to reduce increased motility of Intestines in IBS. It also helps to reduce the inflammation of walls of intestine ${ }^{47}$.

Precaution: This herb should not be used in excess and pregnant women have to avoid consuming Bibhitaki ${ }^{48,49}$.

\section{PHARMACOLOGICAL ACTIVITIES}

A chemical agent that modifies the immune response or the functioning of the immune system is referred as immunomodulator. This is commonly known that macrophages gives role in different mechanism against the infection of host and used in destroying the tumor cells. T. belerica fruit extract possess immunomodulatory activity which is proved by phagocytic and lymphocyte proliferation activity of fruit methanolic extract on the mouse. Where methanolic extract has been reported to stimulates the production of superoxide anions and acid phosphatase then it may promote the macrophage phagocytosis. T. belerica extract with cocanavalin A and pokeweek mitogen caused suppressant activity. Whereas acetone extracts of $T$. belerica has been shown to increase the B- and T-cells proliferation along with increased IL-10 secretion whereas it reduced the production of IFN-a and IL-250

\section{$\beta$-Lactamase inhibitor Activity}

The $\beta$ lactamase inhibitor activity of 68 extracts from Indian herbs and spices was surveyed. Most promising results of the $\beta$ lactamase inhibitor activity invivo and invitro were achieved from the herbal extracts of Bibhitaki. Ginger (Zingiberofficinales), Brahmi (Bacopamonnieri), Garlic (Allium sativum), Gurmar( Gymnemasylvestre), Satavar ( Asparagus racemosus), peels and seeds against Staphylococcus aureus as the test organism ${ }^{51}$.

\section{Antibiofilm Activity}

The ethanolic extract of a plant Baheda was tested for its antimicrobial activity against the oral plaque forming bacteria i.e. Streptococcus mutans. Used in a inhibition of formation of biofilm. Mostly investigates that the plant extract may showed activity against Streptococcus mutans. The extract also prevents in the formation of biofilm with the help of bacteria. The study explains the benefits of this herbal preparation which inhibits the biofilm formation by streptococci, oral pathogens ${ }^{52}$.

\section{Antiulcer Activity}

The antiulcer activity of ethanolic extract of Baheda fruits an ETB was searched out in pylorus ligation and ethanol also may help to produce ulcer models in $r$ rats. In both models the common parameter determined was ulcer index. ETB at doses of $250,500 \mathrm{mg} / \mathrm{kg}$ orally produced significant inhibition of the gastric lesions induced by Pylorus ligation induced ulcer \& Ethanol induced gastric ulcer. The extract $(250 \mathrm{mg} / \mathrm{kg} \& 500$ $\mathrm{mg} / \mathrm{kg}$ ) showed significant reduction in free acidity and ulcer index as compared to control ${ }^{53}$.

\section{In Vitro Glucomylase Activity}

T. belerica fruit rind powder was assessed for its antimicrobial activity by using Chloroform-Ethyl Acetate fractions. Maximum zone of inhibition was observed in both fractions. The fractionized compound Epigallocatechin gallate showed significant antimicrobial activity against E. coli , B subtilis and S.Aureus ${ }^{54}$.

\section{Wound healing actvity}

Wound healing is a complex phenomenon which includes a number of processes such as migration and proliferation of both epithelial and connective tissues, formation of extracellular matrix proteins, alteration of connective tissue, parenchymal components, collagen synthesis. The wound healing potential of extract has been reported in rabbit model. 
Extract paste (500mg/animal) was applied to skin incision weight, blood chemistry initiatives. The results of from the dorsal area of rabbit. Significant increase in the levels examinations showed normal appearance of the internal of hydroxyproline, DNA and uronic acid contents and organs when compared to those of the control group ${ }^{49}$. improvement on maturation, wound contraction and epithelialization was observed between 4-12 days. The study suggested that the herbal paste from $T$. chebula and $T$. belerica enhanced fibroblast function, improved production of glycosaminoglycan and deposition of collagen which is required for wound healing and may be useful in wound healing process 55 .

\section{Analgesic Activity}

\section{Antispasmodic and Bronchiodilatory Activity}

T. belerica fruit extract may promote the relaxation of spontaneous contractions in isolated rabbit jejunum and guinea pig ileum. In guinea pig trachea, TB relaxed the carbachol induced contractions. In which protective effect of TB against castor oil induced diarrhea ${ }^{2}$. It also reserves the $\mathrm{CCH}$ and $\mathrm{K}+$ - induced contractions in a pattern which is similar to that of dicyclomine. Carbachol may induce mediated

T. belerica extracts also have antisecretory and analgesic bronchoconstriction also observed in rodents ${ }^{60}$. activities. The extract have dose range of $300-1000 \mathrm{mg} / \mathrm{kg}$ inhibited the castor oil-induced intestinal fluid secretion in mice. The extracts also dose dependently $(50-100 \mathrm{mg} / \mathrm{kg})$ where it may reduce the numbers of acetic acid in mice. These are the results which indicate that TB exhibit antisecretory and antnociceptive effects, hence justifying its medicinal use in diarrhea and pain ${ }^{56}$.

\section{Antidiarrhoeal Activity}

By using castor oil the Anti diarrhoeal activity was performed to induced diahrroea. Mainly PGE2 induced entero pooling and gastrointestinal motility test. Aqueous and ethalonic extract of fruit pulp of TB at the doses of $334 \mathrm{mg} / \mathrm{kg}, 200 \mathrm{mg} / \mathrm{kg}$ were used. By this in the comparison of percentage initiate on these models showed that the extracts have anti secretory effect.An activity of reproductive system in rats. It was determined that Adult male rats were administered with $10 \mathrm{mg} / 100 \mathrm{~g}$ body weight of benzene and ethanol extracts of Terminalia belerica barks orally for 50 days. Repeated administration of TB bark extract results that it decreased weight of the reproductive ducts in male rats ${ }^{48}$.

\section{Antidiabetic Activity}

Hexane, Ethylacetate and Methalonic extracts of TB fruits at the different doses of 200,300 and $400 \mathrm{mg} / \mathrm{kg}$,p.o for 60 days to Streptozotocin induced diabetic rats by increasing the plasma insulin, C-peptide and glucose tolerance levels, serum total protein, body weight. By adding of plant extracts it may decrease the serum levels of total cholesterol, triglycerides, urea, uric acid and creatinine in diabetic rats ${ }^{57}$.

The reduction of glucose level and Oxidant enzymes such as Superoxide dismutase, glutathione reductase and acatalase were observed in blood and liver. Oxidative stress arise from an imbalance in the formation and metabolisms of reactive oxygen species (ROS). Antioxidants are the molecules that inhibit or reduce free radical reactions and finally prevent cellular damage. Both forms of antioxidants (enzymatic and non-enzymatic) are present in the intracellular and extracellular environments 59 .

\section{Antipyretic Activity}

The antipyretic activity of ethanolic and aqueous extract of Baheda fruits $(200 \mathrm{mg} / \mathrm{kg})$ was studied in brewer's yeastinduced fever models in mice and rats. Both of extracts showed that inhibition of elevated body temperature when compared to corresponding control 58

\section{Acute and Sub-Acute Toxicities}

The acute and sub-acute studies were conducted as per the guidelines of OECD. Single oral administration of the ethanolic extracts of $T$. belerica at a dose of $5,000 \mathrm{mg} / \mathrm{kg}$ did not produce any toxicity. In sub-acute toxicity, repeated administration of $1,000 \mathrm{mg} / \mathrm{kg}$ of $T$. belerica in 14 days which may not cause change in various effects of behaviours, mortality test, gaining

\section{In Vitro Cellular Toxicity}

In present study, ether, chloroform, acetone, alcoholic extract, and of Baheda fruit used for screening. When compared with other extracts both alcoholic and aqueous extracts of TB showed anti-salmonella activity. There was no cytotoxicity was observed in invitro cellular toxicity study ${ }^{60}$.

\section{In Vitro Immune Response}

In vitro Phagocytic activity and lymphocyte proliferation assay were carried out methanolic extract of on the mouse immune system. In evaluations, incentive of macrophage phagocytosis and activation of phytohemagglutinin were observed. Finally, the authors concluded that the methanolic extract of T. belerica affected on the mouse immune system, specifically cellular and humoral immune response in vitro ${ }^{5}$.

\section{Anti-salmonella Activity}

T. belerica showed effects against Salmonella typhii and Salmonella typhimariam. Invitro cellular toxicity also performed by them. In this study different chemicals are used for the screening such as ether, chloroform, acetone, alcohol, of the plant. When compared with other extracts alcoholic and aqueous extracts of plant showed anti salmonella activity. And no toxicity was observed in invitro cellular toxicity study 60 .

\section{Antihypertensive Activity}

The effect of T. belerica in hypertension. After administration of $T$. belerica, they observed that fall in the arterial BP of rats under anaesthesia. In isolated guinea pig atria, inhibition of force and rate of atrial contractions noted. In thoracic aorta of rabbit, relief observed after the administration of contractions which was produced by giving phenylephrine 56 .

\section{Hepatoprotective Activity}

The protective effects of TB fruit extract and its active constituents against $\mathrm{CCl} 4$ in toxicity. Treatment with extract $(50,100$ and $200 \mathrm{mg} / \mathrm{kg}$, p.o.) showed dose dependent recovery in parameters such as SGOT, SGPT and lipid peroxidase, glutathione but the effect of Galli acid is more reliable 61 . The liver is a vital organ of vertebrates and some other animals. ${ }^{62}$. Hepatotoxicity refers to inability of liver to detoxify the toxic compounds. In this one of the most sensitive and dramatic indicators of hepatocyte injury is the release of intracellular enzymes, such as transaminases and serum alkaline phosphatase in the circulation during hepatic abnormalities. Pharmacological activities of the enzymes are useful of cellular drainage and loss of morality of cell membrane in liver63. Methanolic extract of $T$. belerica fruit has both reducing power as well as iron chelating activity and by tjis it may reduce the toxic level of iron in iron overload mice and hence protects liver from oxidative stress and fibrosis. Its administration lowered serum enzyme and serum ferritin levels, which act as a indicators of severe iron overload ${ }^{64}$. 


\section{Antimicrobial Activity}

T.belerica has shown potent action against infectious agents in A myocardial and cerebral infraction is serious consequences vitro. Fruit extracts contains phenol, tannins, alkaloid, and of the thrombus formed in blood vessels. A thrombus formed flavanoids. Alkaloids are mainly responsible for inhibiting the in circulatory system with the failure of haemostasis. microorganisms by impairing the enzymes involved in energy Thrombolytic agents are used to remove the previous blood productions, interfering with the integrity of cell membrane clots from blood vessels ${ }^{70}$. used an invitro model to check the and structural component synthesis. In the fruit extract of $T$. antithromobolytic effect of alcoholic and aqeuous extract of $T$. belerica have tannins may be useful in preventing the belerica fruits. Striptokinase is used as a positive contol. The formation of microorganisms. T.belerica extracts inhibit the study showed that extract delayed the clot formation ${ }^{71}$.

activity of this enzyme when S.aureas grown in the presence of T. belerica extract. The aqueous fruit extract has shown activity against numerous pathogenic bacteria viz. Eschrechiacoli, Pseudomonas aeruginosa, etc. T. belerica also showed antibacterial activity against many Gram positive and Gram negative bacteria including Corynebacterium rubrum, Staphylococcus epidermidis, K. pneumonie etc. However, studies have demonstrated that antibacterial activity was associated with the polar extracts 65 .

\section{Anti-mutagenic Activity}

Water, acetone, and alcoholic extracts of Terminilia belerica were found for their antimutagenic activity by using the various assay on of them is to be Ames Salmonella asay. Acetone extract exhibited variable inhibitory activity of $65.6 \%$ and $69.7 \%$ with $4-0$-nitropenylenediamine and sodium azide , and $81.4 \%$ with 2 -aminofluorene, in the preincubation mode of experimentation. Inhibition with choloroform and water extracts was rather insignificant ${ }^{66}$.

\section{Anti-urolithiatic Activity}

Antirolithiatic activity of fruits of the Terminilia belerica on ethylene glycol induced renal caluculi in albino rats. In which renal stone was induced in rats around $0.75 \%$ ethylene glycol by drinking water for 25 days. After that a test dose are given with alcoholic extract of plant at different doses forms i.e. $100,200,400 \mathrm{mg} / \mathrm{kg}$ b.w.once a day. Till $15-28^{\text {th }}$ day. Where cystosone $(750 \mathrm{mg} / \mathrm{kg}$ ) used as standard drug. The effect of plant on various parameters in urine also in serum was evaluated. The results demonstrated that Met B $(400 \mathrm{mg} / \mathrm{kg})$ reduced the ethylene glycol induced disturbance in different parameters in urine or serum ${ }^{67}$.

\section{Nephrotoxic Effects}

The rats were devided into 5 groups where $1^{\text {st }}$ groups served as a control and injected with normal saline, $2^{\text {nd }}$ group injected with Gentamicin or Silymarin $100 \mathrm{mg} / \mathrm{kg}$ p.o. , $4^{\text {th }}$ or $5^{\text {th }}$ group were injected with Terminilia belerica ethanolic or aqueous extracts plus gentamicin for 15 days $.2^{\text {nd }}$ group showed early kidney dysfunction as serum urea, uric acid and creatnine which may increases. It indicates that GM induced nephrotoxicity. Administration of T. belerica plus gentamicin may protect kidney tissue against nephrotoxic effects ${ }^{68}$.

\section{Angiogenesis Activity}

The angiogenic potential of $T$. belerica by invivo mice sponge implantation assay. Here are gelatin sponge with or without ethanolic extract of $T$. belerica leaf were subcutaneously injected into albino mice and after 14 days the implanted sponges were excised and that section evaluate the presence of sponge. In which EETB may produce various blood vessels in gels which can sponges individually. Another vessels were filled in with red blood corpusules which may shows the formation of a fibro vascular inside the sponges and blood may circulate in another formed of vessels by angiogenesis produced by EETB. Thus ethanolic extract of the plant leaf inhibit the profound angiogenic activity invivo ${ }^{69}$.

\section{Mastitis Activity}

Mastitis is most affecting disease of diary industries.This study was to evaluate the antibacterial effects of hot aqueous extraction (HAE) of the fruits of Terminilia belerica on field isolates of mastitis. HAE of the fruits of $T$. belerica make mixture with another selected plants and used for their synergistic/antagonistic effect. The antibacterial potential was determined by disc diffusion method. The inhibition zone decreases after $24 \mathrm{hrs}$ which may show effect as bacteriostatic rather than bacteriocidal. After all this is justified that the use of Triphala as a compound of Bahera treat the clinical/subclinical mastitis 72 .

\section{Toxicity Study and Anti-inflammatory Activity}

Terminalia belerica extract administered at different doses such as $2000-1000 \mathrm{mg} / \mathrm{kg}$ in acute or subacute toxicities studies. Antiinflammatory activities of T. belerica extract evaluated in carrageenan induced paw edema model. For the activity, the animals were divided into 5 gps. They have different doses such as Group-1 control, Group-2 Indomethacin $3 \mathrm{mg} / \mathrm{kg}$, Group-3 TBE $100 \mathrm{mg} / \mathrm{kg}$, Group-4 TBE $200 \mathrm{mg} / \mathrm{kg}$, Group- 5 TBE $400 \mathrm{mg} / \mathrm{kg}$. Then the results show that the mortality and signs are non observeable in acute and repeated toxicity studies after administration of TBE dose of $2000 \mathrm{mg} / \mathrm{kg}$. Antiinflammatoy activity showed in carrageenan induced paw edema model 1,3and $5 \mathrm{~h}$. A inhibition of paw as compared to control gp. was observed at different doses 100,200 and $400 \mathrm{mg} / \mathrm{kg}$ at 1,3 and $5 \mathrm{~h}$. and comparable efficacy has be shown of indomethacin at $200 \mathrm{mg} / \mathrm{kg}^{73}$.

\section{Antibacterial Activity}

The antimicrobial activity was evaluated by using agar well diffusion method against the Gram -ve or Gram +ve bacteria such as Staphylococcus aureus, Staphylococcus epidermidis, Bacillus aureus, Pseudomonas aeruginosa, Salmonella, Escherichia coli and Azotobacter etc. These bacterias are isolates using methanol, ethanol, acetone, chloroform and leaf extract of T. belerica. All by this it was observed that the ethanolic extracts gives the good activity against the tested bacterial isolates, as comparatively methanol, chloroform, or aqeuous extract also. Hence, this study states that the Triphala and its constituents may reveal antibacterial activity against the human pathogenic bacteria ${ }^{74}$.

\section{Antioxidant Activity}

Due to imbalancing in generation and metabolism of ROS an oxidative stress has been arise, when the more ROS produced than that is metabolized 75 . The supplements used as antioxidants are help to reduce oxidative agents ${ }^{76}$. The present study evaluated the antioxidant activity of $T$. belerica fruits. The study was to evaluate the antioxidant study, total phenolics, flavanoids content of aqeuos(AETB)and ethanolic extract(EETB) of fruits of $T$. belerica ${ }^{77}$. The antixidant activity was investigated by DPPH(1,1-diphenyl-1,2-picryl hydrazyl), ABTS(2,2-Azino-bis 3-ethyl benothiazoline-6 sulphonic acid diammonium salt, superoxide, nitric oxide, reducing power and TAC(Total antioxidant capacity) ${ }^{78}$. The higher antioxidant 
activity has been shown by AETB as compare to EETB in nitric oxide, superoxide etc. In antioxidant activity the reducing power increases in dose dependent manner which may show higher absorbance at $700 \mathrm{~nm}$ for AETB that is $0.95+-0.03$ as compare to EETB which is $0.43+-0.01$. The total phenolic and flavanoids amount were also determined. The antioxidant activity of $T$. belerica fruit were contributes by TPC and TFC 75 .

\section{Anticancer Activity}

In Ayurveda the main constituent of T. belerica is Triphala which may have the cytotoxic effects against different cancer cells, breast cancer cell, pancreatic cancer cell, prostate cancer cell. The acetone extract of $T$. belerica exhibited antimutagenic potency using microsome assay. These extracts are having different inhibitory activity $65.6 \%$ and $69.7 \%$ with $4-0$ nitrophenylenediamine and sodium azide also ${ }^{66}$.

\section{Anti-obesity Activity}

The study investigated the effect of ethanolic extract of fruits of Terminalia belerica on Atherogenic diet which may induced obesity in rats. The rats were devided into 4 groups i.e. group1-control rat, group2- obesity control, group3- obesity $+500 \mathrm{mg} / \mathrm{kg}$ fruit body weight of extract of $T$. belerica, group 4 obesity $+10 \mathrm{mg} / \mathrm{kg}$ body weight of sibutramine. Body temperature, weight gain, feed and water intake, BMI and lipid profile were measured. The continuous administration of ethanolic extract of T. belerica at the dose of $500 \mathrm{mg} / \mathrm{kg}$ had significant effect in the parameters similar to drug of Sibutramine. The ethanolic extract of Terminalia belerica is useful in the treatment of obesity ${ }^{79}$.

\section{CONCLUSION}

The extensive survey of literature revealed that Terminalia belerica, it is an important medicinal plant with various pharmacological spectrum. Further study of ayurvedic human uses of herbs, is found as an useful for the locate advanced medicaments. In which one of the plant ofTerminalia belerica is widely used in Ayurveda. Crude extracts of various parts of Terminalia belerica plant have been found to contain constituents such as Glucoside, Gallo-tannic acid, colouring matter, resins, ellagic acid, gallic acid, lignans, termilignan, ethyl gallate, phenyllemblin Tannins, mannitol, fructose, rhammnose. These compounds are responsible for the pharmacological activities i.e. antimicrobial, antioxidant, antisalmonella, hepatoprotective, antispasmodic, and anticancer activities. Further the plant is used in the treatment of gastric ulcer, constipation, piles. Hence, this plant provides a significant role in the prevention and treatment of disease. Further evaluation needs to be carried out in order to explore the concealed areas and their practical clinical applications, which can use for the welfare of the mankind.

\section{REFERENCES}

1. Farnsworth NR, Soejarto DD. Global importance of medicinal plants. The conservation of medicinal plants. 1991; 26:25-51

2. Gilani HA, Khana A, Tuba Ali T and Ajmal S. Mechanisms underlying the antispasmodic and bronchodilatory properties of Terminalia belerica fruit. J Ethnopharmacol. 2008;528

3. Chandran U, Patwardhan B. in Innovative Approaches in Drug Discovery. 2017

4. Baliga MS, Haniadka R. Foods and Dietary Supplements in the Prevention and Treatment of Disease in Older Adults. 2015

5. Saraphanchotiwitthaya A, Sripalakit P and Ingkaninan K. Effects of Terminalia belericaRoxb. Methanolic extract on mouse immune response in vitro. MaejoInternational Journal of Science and Technology. 2008; 400.

6. Mallik J, Das P, Karon B, Das S. A review on phytochemistry and pharmacological activity of Terminalia belerica. International journal of drug formulation and research. 2012; 3(6):1-5.
. Mahboubi M, Shahcheraghi F, Feizabadi M M. Bactericidal effects of essential oils from clove, lavender and geranium on multi-drug resistant isolates of Pseudomonas aeruginosa. In Iranian Journal of Biotechnology. vol. 4. 2006; 137- 40.

8. Oke JM, Hamburger MO. Screening of some Nigerian medicinal plants for antioxidant activity using 2, 2, diphenyl-picryl-hydrazyl radical. Afr. J. Biomed. Res. 2002; 5:1-2.

9. Atal CK, Sharma ML, Kaul A, Khajuria A. Immunomodulating agents of plant origin. Preliminary screening. J Ethnopharmacology 1986; 41:185-192.

10. Hung JW and Chung WC. Management of vegetable crops disease with plant extracts. Adv Plant Dis Management. 2003; 37:153-163.

11. Kumudhavalli MV, Vyas M and Jayakar B, Phytochemical and pharmacological evaluation of the plant fruit of Terminalia bellirica Roxb, Int I Pharm Life Sci. 2010; 1(1): 1-11.

12. Pingale SS. Hepatoprotective action of Terminalia belerica on $\mathrm{CCl} 4$ induced hepatic disorders. Der Pharm Chemi. 2011; 3:42-48.

13. Alam B. Antioxidant, Antimicrobial and Toxicity studies of the Different Fractions of Fruits of Terminalia belericaRoxb. Global Journal of Pharmacology. 2011; 17.

14. Kumar B, Divakar K, Tiwari P, Salhan M, Goli D. Evalution of AntiDiarrhoeal Effect of Aqueous And Ethanolic Extracts of Fruits Pulp of Terminalia belerica In Rats. International Journal of Drug Development and Research. 2010; 779.

15. Gilani AH, Khan AU, Ali T, Ajmal S. Anti-Spasmodic and Bronchodilatory Properties of Terminalia belerica Fruit.Journal of Ethnopharmacology.2008; 538

16. .Meena AK, Yadav A, Singh U, Singh B, Sandeep et al, Evaluation of physicochemical parameters on the fruit of Terminalia bellirica Roxb. Int J Pharmacy Pharm Sci. 2010;2:96-98.

17. Karthikeyan M, Kannan M, Rajasekar S and Saraswathi MN Terminalia belerica Roxb. A Phytopharmacological Review. Int J Res Pharm Biomed Sci. 2012; 3:96-99.

18. Das P, Karon B, Das S, and Mallik J. A review on phytochemistry and pharmacological activity of Terminalia belerica. Int J Drug Form Res. 2012; 07

19. Abraham A, Mathew L, and Samuel S. Pharmacognostic studies of the fruits of Terminaliabellirica (Gaertn.) Roxb. J Pharm Phytochem. 2014; 52.

20. Saroya AS. Herbalism phytochemistry and Ethnopharmacology. Science Publishers.2011; 361.

21. http://www.worldagroforestry.org/treedb/AFTPDFS/Ter minalia_bellirica.PDF,https://www.easyayurveda.com/2013/01/1 3/bibhitakibaheda-terminalia-bellerica-uses-ayurveda-details

22. Sharma A. Terminalia bellirica medicinal uses and pictures. (http://www.homeremediess.com/ terminalia-bellericamedicinal-uses-and-pictures). 2015.

23. Nadkarni K M, Indian Meteria Medica (Popular Prakashan Pvt. Ltd. Mumbai). 2002; 1202-1205.

24. Singh A. Medicinal Plants of the World (Oxford and IBH Co. Pvt, New Delhi). 2006; 26

25. Anand KK, Singh B, Saxena AK, Chandan BK, Gupta VN and Bhardwaj V. The Hepatoprotective principle in the fruits of Terminalia bellirica bioassay guided activity. Pharmacol Res. 1997; 36: 315-321.

26. Molla MTH, Alam MT and Islam MA. Physico-chemical and nutritional studies of Terminalia bellirica Roxb. seed oil and seed kernel. J Bio-Sci. 2007; 15: 117-126.

27. Nandy A K, Podder G, Sahu N P and Mahato S B. Triterpenoids and their glucosides from Terminalia bellerica. Phytochem. 1989;28: 2769-2772.

28. Row L R and Murty P S. Chemical examination of Terminalia bellirica Roxb. Indian J Chem.1970; 8: 1047-1048.

29. Valsaraj R, Pushpangadan P, Smitt U W and Adsersen A. New antiHIV-1, antimalarial, and antifungal compounds from Terminalia bellerica. J Nat Prod. 1997; 60(7):739-742.

30. Khan A U, Hassan A and Gilani, Pharmacodynamic evaluation of Terminalia bellirica for its anti-hypertensive effect. J Food Drug Anal.2008; 16: 6-14

31. Bade JD, Ahera AN, Mandal SC, Belsare DP and Pal SC. Isolation and characterization of hydrolysable tannins from leaf of Terminalia bellirica Roxb. J Pharm Res. 2010; 3: 2410- 2414.

32. Ayoob FA, Awad HM, El-Kousy SM, Rashed KN and Al-Sayed N H. Phytochemical and biological investigations of Terminalia bellirica Roxb. leaves. J Pharm Res. 2014; 8(4) 500-510.

33. Shankar M, Teja TL, Ramesh BD, Kumar R, Ramanarao D N V, et al. Phytochemical investigation and antibacterial activity of 
hydroalcoholic extract of Terminalia bellirica leaf. Asian J Phytomed Clin Res. 2014; 2(1):33 - 39.

34. Refahy L A and Saad M A. Characterization of chemical constituents,reducing power and anticancer activities of Terminalia bellirica Roxb. Acad J Cancer Res. 2014;7(2): 117-125.

35. Vaidyaratnam PS. Indian Medicinal Plants. Published by Orient Longman Private Ltd. Chennai.2004; 5: 258-262

36. Roy S K, Pal P K and Das A K . Propagation of a timber tree Terminalia bellirica Roxb. by tissue culture. Bangladesh J Bot. 1987; 16:125-130.

37. Rastogi RP and Mehrotra BN. Compendium of medicinal plants central drug research institute (CDRI), Lucknow and National institute of communication and information resources. New Delhi. 2004; 406

38. Kirtikar KR and Basu BD. Indian medicinal plants. 2nd edn (International Book Distributors, Dehradun).1999.

39. Ghani A. Medicinal plants of Bangladesh with chemical constituents and uses. Asiatic Society of Bangladesh. Dhaka Ramna. 2003;184.

40. Aneja KR, Sharma C and Joshi R. Antimicrobial activity of Terminalia arjuna Wight \& Arn an ethnomedicinal plant against pathogens causing ear infection. Braz J Otorhinolaryngol. 2012; 74.

41. Devi PN, Kaleeshwari S and Poonkothai M. Antimicrobial activity and phytochemical analysis of fruit extract of Terminalia belerica. Int J Pharm Pharma Sci. 2014; 642.

42. Fahmy NM, Al-Sayed E and Singab AN. Genus Terminalia A phytochemicals and biological Review. Med Aroma Plants. 2015 21.

43. Saroya SA. Herbalism phytochemistry and ethnopharmacology (Science Publishers).2011; 357-361.

44. Guleria S, Tiku AK and RanaS. Antioxidant activity of acetone extract/ fractions of Terminalia bellericaRoxb. Fruit. Ind J BiochemBiophys. 2010; 110.

45. Hanahan D, and Weinberg RA,The hallmarks of cancer. Cell. 2000; 57 .

46. Kadian R, Parle M, Yadav M. Therapeutic potential and phytopharmacology of Terminalia bellerica. WJPPS. 2014 3(10):804-19

47. SaxenaV, MishraG, Saxena A and Vishwakarma K.K . A comparative study on quantitative estimation of tannins in Terminalia Chebula Terminalia Belerica, Terminalia Arjuna and Saraca indica using spectrophotometer. Asian J Pharm Clin Res. 2013; 6:148-149.

48. Sharangouda J, Satishgouda S, Vishwanatha T and Saraswati B. Effect of Terminalia belerica barks extracts on activties of accessory productive ducts in male rats. International Journal of Pharmaceutical science Review and Research. 2014; 75.

49. Thanabhorn S, Jaijoy K, Thamaree S, Ingkaninam K. Acute and Subacute Toxicities of the Ethanol Extract of fruit of Terminaliabelerica. Journal of Pharmacuetical sciences.2009. The Ayurvedic Pharmacopoeia of India. $1^{\text {st }}$ edition published by the controller of Publications. Civil Lines, New Delhi. 2001; 1(01):252.

50. Saraphanchotiwitthaya A, and Ingkaninan K. Immunomodulatory activity of an acetone extract of Terminaliabelericaroxb fruit on the mouse immune response in vitro. Int J Pharm Pharma Sci. 2014 274.

51. Shaikh S, Lochan R, Kaul P, Tandon GD. Beta lactamase Inhibitors from Indigenous Herbs and Spices. Res. J. of Pharmaceutical. Biological and Chemical Sci. 2001; 275.

52. Yadav S, Singh S, Sharma P, Thapliyal A, Gupta, Antibiofilm Formation Activity of Terminaliabellerica Plant Extract Against Clinical Isolates of Streptococcus mutans and Streptococcus sobrinus. Implication in Oral Hygiene. Int. J of Pharmaceu. \& Bio Arch. 2012; 816

53. Choudhary GP. Anti-ulcer activity of the ethanolic extract of Terminalia belericaRoxb. Int. J. of Pharmaceutical and Chemical Sci. 2012; 97.

54. Gangadhar M, Patil B, Yadav S, and SindeD. Isolation and characterization of gallic acid from Terminalia belerica and its effect on carbohydrate regulatory system in vitro. Int J Res Ayur Pharm. 2011; 562.

55. Saha PK, Patrab PH, Pradhan R, RadharamanDey, Shyamal Das, Mandal TKV. Effect of Terminaliabelerica\&Terminaliachebula on wound healing in induced dermal wounds in Rabbits. Pharmacology online. 2011; 235.
56. Khan AU, Gilani AH. Pharmacodynamic Evaluation of Terminalia belerica for its Anti-Hypertensive Effect. Journal of Food and Drug Analysis. 2008; 14.

7. Latha PCR, and Daisy P. Influence of Terminalia belerica Roxb. Fruits Extract on Biochemical Parameters. In Streptozotocin Diabetic Rats. International Journal of Pharmacology.2010; 89.

58. Sharma SU, Sharma US, Singh A, Sutar N, Singh PJ. Screening of Terminaliabellirica Fruits Extracts for its Analgesic and Antipyretic Activities. Jordan J of Bio Sci. 2014; 121.

59. Sabu MC and Kuttan R. Anti diabetic and Anti oxidant activity of Terminaliabelerica Roxb. Indian Journal of Experimental Biology. 2009;270.

60. Madani A, Jain SK, Anti-Salmonella Activity of Terminaliabelerica In vitro and in vivo Studies. Indian Journal of Experimental Biology. 2008; 817.

61. Shukla S, Jadon A and Bhadauria M. Protective effect of Terminaliabelerica Roxb and gallic acid against carbon tetra chloride induced damage in albino rats. Journal of Ethnopharmacology.2008; 214

62. Abdel M, Sherif RZ and Bloomston M. Liver Anatomy. Surg Clin North America. 2010; 90:643-653.

63. Rajesh MG and Latha MS .Protective activity of Glycyrrhiza glabra Linn. on carbon tetrachloride-induced peroxidative damage. Ind J Pharm.2004; 36:284-287.

64. Hazra B, Sarkar R. and Mandal N. Protection of Terminalia bellerica Roxb. against iron overload induced liver toxicity. An account of its reducing and iron chelating capacity. Am J Pharm Toxicol.2012; 7:109-122.

65. Elizabeth KM. Antimicrobial activity of Terminalia bellerica. Ind ClinBiochem. 2005; 153.

66. Kaur S, Arora S, Kaur S, Kumar S. Bioassay-guided isolation of antimutagenic factors from fruits of Terminalia bellerica. J Environ PatholToxicol Oncol. 2003; 69

67. Upadhyay N, Tiwari S K, Srivastava A, Seth A, and Maurya S K Anti-urolithiatic effect of Terminalia bellirica Roxb. fruits on ethylene glycol-induced renal calculi in rats. Indo Am J Pharm Res. 2015; 5(5): 203.

68. .Fatima $\mathrm{N}$ and Sultana $\mathrm{H}$. Evaluation of protective effect of Terminalia bellirica against gentamicin induced nephrotoxicity in albino rats. Pharmaceut Biol Evaluat. 2016; 3(5)486:494

9. Prabhu VV, Chidambaranathan $\mathrm{N}$ and Gopa V. Evaluation and quantification of angiogenesis activity of Terminalia Bellirica Roxb. by mice sponge implantation method. J Young Pharm. 2012; $4(1): 22-27$.

70. Prasad S, Kashyap RS, Deopujari JY, Purohit HJ, Taori GM et al Effect of Fagoniaarabica (Dhamasa) on in vitro thrombolysis. BMC Complement Altern Med. 2007; 7: 36.

71. Ansari AV, Siddiqui $\mathrm{HH}$ and Singh PS. Antithrombotic and thrombolytic activity of Terminalia belerica fruit extracts. Res J Pharm BiolChemSci. 2012; 78

72. Varshney S, Varshney P, Dash SK, Gupta KM, Kumar A, Bist B and Sharma A. Medicinal Plants. 2012; 4(3) : 167-169

73. Gupta R, Singh RL, Gupta A. Antioxidant, DNA protective and antibacterial activities of Terminalia bellerica extracts. Vol.13.2019; 431-442.

74. Chauhan P, Singh S, Gupta YK, Kumar U.Downloaded free from http://www.jnsbm.org on, 2020;IP: 106.205.168.124.

75. Chavan LV, Anita P, Naresh C. Antioxidant Availabiltiy of Beheda (Terminalia bellerica (Roxb.) in Relation to its Medicinal Uses. 2010

76. Young IS and Woodside JV. Antioxidant in health and diseases. Clin Path. 2004: 54: 176-186.

77. Vani T, Rajani M, Sarkar S \& Shishoo CJ. Antioxidant properties of the ayurvedic formulation triphala and its constituents. International Journal of Pharmacognosy. 1997; 35(5):313-317

78. Pfundstein B, Desouky El, Hull SK, Haubner WE, Erben RG \& Owen RW . Polyphenolic compounds in the fruits of Egyptian medicinal plants (Terminalia bellerica, Terminalia chebula and Terminalia horrida) characterization, quantitation and determination of antioxidant capacities. Phytochemistry. 2010; 71(10):1132-1148.

79. Das CMS and Devi SG. Journal of Chemical and Pharmaceutical Research. 2016; 8(3):191-197 